\title{
The chemical and biological characteristics of coke-oven wastewater by ozonation
}

\author{
E.-E. Chang a , Hao-Jan Hsing ${ }^{\text {b, } *}$, Pen-Chi Chiang ${ }^{c}$, Mei-Yin Chen ${ }^{c}$, Jhieh-Yu Shyng ${ }^{d}$ \\ ${ }^{a}$ Department of Biochemistry, Taipei Medical University, 250, Wu-Shin Street, Taipei, Taiwan, ROC \\ ${ }^{\mathrm{b}}$ National Science \& Technology Center for Disaster Reduction, 9F, 200, Section 3, Beisin Road, Xindan City, Taipei County 231, Taiwan, ROC \\ ${ }^{c}$ Graduate Institute of Environmental Engineering, National Taiwan University, 71 Chou-Shan Road, Taipei 106, Taiwan, ROC \\ ${ }^{\mathrm{d}}$ Department of Information Science, Lan Yang Institute of Technology, 79, Fusing Road, Touchen Township, Yilan County 261, Taiwan, ROC
}

Received 11 July 2007; received in revised form 25 November 2007; accepted 18 December 2007

Available online 6 January 2008

\begin{abstract}
A bench-scale bubble column reactor was used to investigate the biological and chemical characteristics of coke-oven wastewater after ozonation treatment through the examination of selected parameters. Color and thiocyanate could be removed almost entirely; however, organic matter and cyanide could not, due to the inadequate oxidation ability of ozone to remove ozonated byproducts under given experimental conditions. The removal of cyanide and total organic carbon were $\mathrm{pH}$-dependent and were found to be efficient under neutral to alkaline conditions. The removal rate for thiocyanate was about five times that of cyanide. The ozone consumption ratio approached to about 1 at the early stage of ozonation (time $<20 \mathrm{~min}$ ), indicating that easily degraded matter was present, and mostly ozone was used to oxidize the pollutants. As ozonation progressed, the consumption ratio decreased to 0.2 , and TOC removal ( $\left.\eta_{\mathrm{TOC}}\right)$ increased to $30 \%$, indicating that easily degraded pollutants were degraded almost entirely. The effect of ozonation on the subsequent biological treatment unit (i.e., activated sludge process) was determined by observing the ratio of 5-day biological oxygen demand to chemical oxygen demand $\left(\mathrm{BOD}_{5} / \mathrm{COD}\right)$ and the specific oxygen utilization rate (SOUR). The results indicated that the contribution of ozonation to inhibition reduction was very significant but limited to the enhancement of biodegradation. The operation for ozonation of coke-oven wastewater was feasible under neutral condition and short ozone contact time in order to achieve better performance and cost savings.
\end{abstract}

(C) 2008 Published by Elsevier B.V.

Keywords: Ozonation; Thiocyanate; Cyanide; Total organic carbon; Biodegradation; Inhibition

\section{Introduction}

Coke is the major component in manufacturing steel, which is produced by the pyrolysis of coal. During pyrolysis, cokeoven gases are produced and cooled for further steel-making purposes. The condensed water from coke-oven gases consists of many pollutants that contain refractory compounds, such as tar, ammonia, phenols, naphthalene, light oil, and sulfuric compounds; tar and ammonia can be recovered in a decanter for use in other processes. The liquid remaining after recovery, called coke-oven wastewater, is ready for treatment and discharge into a body of water. The conventional processes used to treat coke-oven wastewater include chemical neutralization,

\footnotetext{
* Corresponding author. Tel.: +88626628 6066x643; fax: +886266282588.

E-mail address: hjhsing@ncdr.nat.gov.tw (H.-J. Hsing).
}

activated sludge process, and sand filtration [1]. Due to the difficulty in removing refractory organic matter, treated wastewater released from conventional processes can not effectively meet current effluent standards; the discharged effluent has become the object of complaints from local communities and the target of inspection [2]. Although some treatment processes, for example, chemical coagulation, ion exchange, and active carbon adsorption [3,4], may achieve high removal efficiencies of organic matter and color, they are accompanied by the high cost of sludge treatment, disposal, and activated carbon regeneration $[5,6]$.

With its high oxidation capability, ozone has been successfully applied in water and wastewater treatment to remove color and reduce the chemical oxygen demand (COD) and total organic carbon (TOC) of wastewater [7-10], as well as to remove cyanide $\left(\mathrm{CN}^{-}\right)$, thiocycanate $\left(\mathrm{SCN}^{-}\right)$[11], and phenolic compounds [12]. Ozonation is a promising method to treat wastewater containing refractory compounds and has been 
applied in the textile, leather tanning, and petrochemical industries.

The objective of this study is to investigate the effects of ozonation on the degradation of target pollutants in coke-oven wastewater under various $\mathrm{pH}$ conditions and the effect on subsequent biological treatment. The experiments were performed in a bench-scale bubble column so that they could be easily controlled. The results of the chemical and biological tests in this study can serve as a reference for evaluating the effectiveness of coke-oven wastewater ozonation and the combination of treatment systems for practical applications.

\section{Materials and methods}

\subsection{Chemicals}

The chemicals used in this study for chemical analysis included potassium buffer (Merck, NJ, USA) to keep the $\mathrm{pH}$ constant at the desired value, KI (Sigma-Aldrich, WI, USA) for calibrating ozone concentration, and phenol standard (Merck). All experimental solutions were prepared with deionized water from Milli-Q purification system (Waters, MA, USA). All chemicals for COD, TOC, 5-day biological oxygen demand (BOD 5 ), $\mathrm{CN}^{-}, \mathrm{SCN}^{-}$, American Dye Manufacturer's Institute (ADMI) color scale, biological growth, and the $\mathrm{pH}$ buffer solution were obtained from Aldrich (WI, USA) and J.T. Baker (NJ, USA).

\subsection{Wastewater}

Wastewater discharged from a local coke plant was used in this study. Table 1 gives the $\mathrm{pH}, \mathrm{COD}, \mathrm{BOD}$, total phenols, suspended solids (SS), and the sample size for the wastewater sampled in this study during 2005.

\subsection{Experiment}

\subsubsection{Ozonation experiment}

Fig. 1 is a schematic diagram of the ozone contacting bubble column. The airtight Pyrex glass column was $50 \mathrm{~cm}$ high
Table 1

The characteristics of raw coke-oven wastewater

\begin{tabular}{lccl}
\hline & Range & Average & Sample size \\
\hline pH & $6.8-8.2$ & 7.52 & 238 \\
Conductivity $(\mu \mathrm{S} / \mathrm{cm})$ & $5328-12670$ & 8855 & 238 \\
$\mathrm{COD}(\mathrm{mg} / \mathrm{L})$ & $930-3120$ & 1950 & 238 \\
$\mathrm{BOD}(\mathrm{mg} / \mathrm{L})$ & $510-1360$ & 924 & 25 \\
$\mathrm{Phenols}(\mathrm{mg} / \mathrm{L})$ & $11.6-533$ & 320 & 238 \\
$\mathrm{CN}^{-}(\mathrm{mg} / \mathrm{L})$ & $12-80$ & 32 & 238 \\
$\mathrm{SCN}^{-}(\mathrm{mg} / \mathrm{L})$ & $275-947$ & 618 & 238 \\
$\mathrm{NH}_{3}-\mathrm{N}(\mathrm{mg} / \mathrm{L})$ & $492-2195$ & 1118 & 238 \\
$\mathrm{SS}(\mathrm{mg} / \mathrm{L})$ & $19-3330$ & 72 & 238 \\
\hline
\end{tabular}

and had an inner diameter of $6.5 \mathrm{~cm}$, with an effective volume $\left(V_{\mathrm{L}}\right)$ of $1.5 \mathrm{~L}$ and free space volume $\left(V_{\mathrm{H}}\right)$ of $0.16 \mathrm{~L}$. It was equipped with a water jacket to maintain a constant solution temperature. The ozonation experiment was operated in a countercurrent mode with raw wastewater flowing downward that was pumped through a monitoring system from the bottom and then back to the column from the top; the ozone-containing gas flowed upward continuously. The ozonated solution was pumped through a monitoring system that contained a $\mathrm{pH} /$ conductivity meter (WTW, Weilheim, Germany) and dissolved ozone sensors (Orbisphere Laboratory, Vesenaz, Switzerland). The water quality data generated by the instruments was transmitted to a computer for real-time analysis.

Ozone-containing gas was generated with pure oxygen by an ozone generator (Sumitomo, Tokyo, Japan) and introduced into the column so that mixed gas flowed through a ceramic diffuser located $5 \mathrm{~cm}$ from the bottom of the column. Before the experiments, the ozone-containing gas flow was measured by an ozone monitor (Dasibi, CA, USA), which was calibrated with a KI solution; the ozone concentration in the off-gas was measured as well. Excess ozone gas leaving the reactor was destroyed as it flowed through a tank filled with activated carbon.

The ozone concentration $\left(C_{\mathrm{Ai}}\right)$ and gas flow rate $\left(Q_{\mathrm{G}}\right)$ at the inlet were pre-set at $94 \mathrm{~g} / \mathrm{m}^{3}$ and $0.5 \mathrm{~L} / \mathrm{min}$, respectively; the $\mathrm{pH}$ value of the raw coke-oven wastewater was pre-adjusted to the

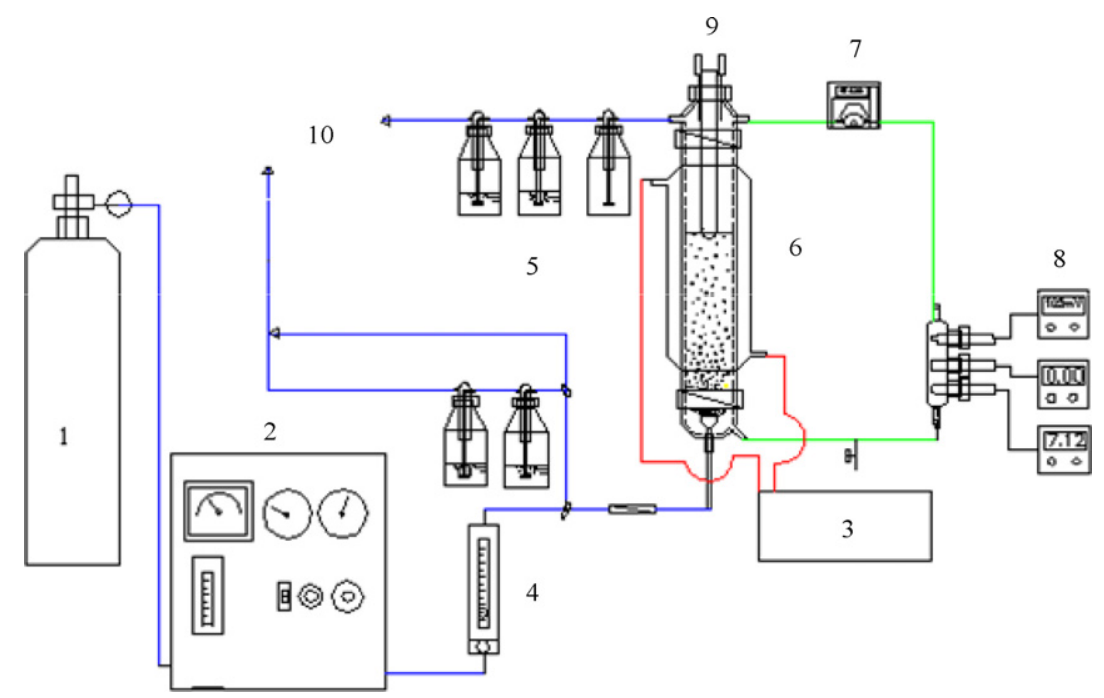

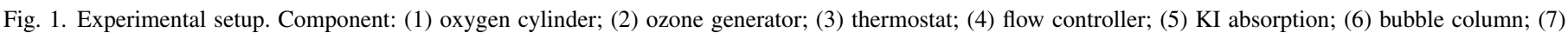
pump; (8) water quality monitor module ( $\mathrm{pH}$, conductivity, dissolved ozone sensor); (9) inject port for $\mathrm{pH}$ adjustment; (10) vent. 


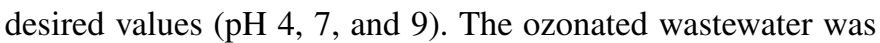
sampled for further analysis of TOC, color, phenol, $\mathrm{CN}^{-}$, and $\mathrm{SCN}^{-}$and for the calculation of ozone consumption.

\subsubsection{Biological experiment}

The activated sludge was obtained from a coke-oven wastewater treatment plant that was treated in a laboratory-scale aeration tank before biological experiments were conducted. The tank dimensions were $20 \mathrm{~cm}(L) \times 10 \mathrm{~cm}(W) \times 20 \mathrm{~cm}(D)$ and effective volume $=9 \mathrm{~L}$; the coke-oven wastewater was continuously fed into the aeration tank at a given flow rate and aerated to maintain a dissolved oxygen (DO) concentration higher than $3 \mathrm{mg} / \mathrm{L}$. The temperature was controlled at $25 \pm 1^{\circ} \mathrm{C}$. During aeration, ammonia was stripped from the wastewater. The $\mathrm{pH}$ was controlled in the range of 6.5-7.5, and the food-to-microorganisms $(F / M)$ ratio was controlled within the range of $0.1-0.2$; nutrients $\left(\mathrm{CaCl}_{2}, \mathrm{MgSO}_{4}, \mathrm{FeCl}_{3}\right.$, and phosphate buffer solution) were added into the raw wastewater to sustain the growth of microorganisms. The hydraulic retention time was $24 \mathrm{~h}$, and the sludge age was maintained at 30 days.

\subsection{Analysis}

A dissolved ozone monitor (Orbisphere Laboratory, Vesenaz, Switzerland) was used to detect the dissolved ozone concentration with a membrane-containing cathode as the sensor; the cathode was previously calibrated using the indigo method. The $\mathrm{pH}$ and conductivity of the solution, as well as the DO, were measured during the segment of the experiment in which data was transmitted to a datalog system. The ADMI method was employed to evaluate the color extent; absorbance at 590, 540, and $438 \mathrm{~nm}$ was also determined for calculating tristimulus values using a UV-visible detector (GBC Scientific Equipment, Victoria, Australia), the standard solution is defined as 500 ADMI color units which was prepared by dissolving $1.246 \mathrm{~g}$ of potassium chloroplatinate $\left(\mathrm{K}_{2} \mathrm{PtCl}_{6}\right), 1 \mathrm{~g}$ of crystalline cobaltous chloride $\left(\mathrm{CoCl}_{2} \bullet 6 \mathrm{H}_{2} \mathrm{O}\right)$, and $100 \mathrm{~mL}$ conc. $\mathrm{HCl}$ into $1 \mathrm{~L}$ of distilled water. The $\mathrm{COD}, \mathrm{CN}^{-}$, and $\mathrm{SCN}^{-}$measurements used the methods listed in APHA.

TOC concentration was measured by a TOC analyzer (O.I. Corporate, CA, USA) that measured the converting amount of organic carbon to carbon dioxide. $\mathrm{BOD}_{5}$ was measured using a BODTrak apparatus (HACH, CO, USA). A reversed-phase HPLC (Agilent, CA, USA) containing a C-18 column (dimension: $5 \mu \mathrm{m}, 25 \mathrm{~cm} \times 0.46 \mathrm{~cm}$ ) and a UV detector (Agilent, CA, USA) were used to determine the concentrations of phenols; the mobile phase was a mixture of water, phosphoric acid, and acetonitrile that was reported in a previous study [13].

\section{Results and discussion}

\subsection{Effects of ozonation on selected parameters}

Due to the complexity and diversity of the components in the coke-oven wastewater, several water quality indicators - i.e., ADMI, TOC, $\mathrm{BOD}, \mathrm{CN}^{-}, \mathrm{SCN}^{-}$, and phenols - were selected to characterize water quality after ozonation, which was carried out at $\mathrm{pH} 7$, temperature $=25{ }^{\circ} \mathrm{C}$, and ozone dose $=94 \mathrm{~g} / \mathrm{m}^{3}$. The results are shown in Fig. 2. Decolorization, which was represented by the change in ADMI over the course of the experiment, was an important indicator of the effectiveness of ozonation. The ADMI values increased with ozonation time up to 2200 units. Then, the value decreased to 223 (Fig. 2a); decolorization was about $70 \%$ and was defined as:

Decolorization $=\left(\frac{1-\mathrm{ADMI}^{\mathrm{ADMI}}}{\mathrm{ADM}_{0}}\right) \times 100 \%$

The ADMI increased at the initial ozonation stage, suggesting that the aromatic compounds of bonding electron-donation substitutes would increase the color intensity; a similar observation was reported previously [14]. Afterward, the ADMI decreased from 21,590 to 223 within 40 min of ozonation, suggesting that organic matter was oxidized by ozone gradually and that the slight amount of color remaining was due to the ozonated byproducts, which may absorb visible light. The decline of TOC and BOD concentration during ozonation is presented in Fig. 2b and c. The concentration of TOC decreased from 460 to about $280 \mathrm{mg} / \mathrm{L}$ after $60 \mathrm{~min}$ of ozonation, and BOD decreased from 833 to $96 \mathrm{mg} / \mathrm{L}$ in the same period. The decomposition trend for TOC at the early stage (within the first $20 \mathrm{~min}$ ) was rapid compared with the later period; the removal rate constants $\left(k_{\mathrm{R}}\right)$ for TOC at 5, 20 and $60 \mathrm{~min}$ were $0.024,0.0096$ and $0.0090 \mathrm{~min}^{-1}$, and the $\mathrm{k}_{\mathrm{R}} \mathrm{s}$ for BOD were $0.12,0.089$, and $0.026 \mathrm{~min}^{-1}$, respectively. The $k_{\mathrm{R}}$ was defined as follows:

$\ln \frac{C}{C_{0}}=-k_{\mathrm{R}} t$

The $k_{\mathrm{R}}$ values for TOC and BOD revealed that removal of both decreased remarkably in the early stage (within $20 \mathrm{~min}$ ) of ozonation, indicating that rapid mineralization happened and formed ozonated byproducts during this period of the process; most of the ozonated byproducts were organic acids that were difficult to oxidize. Similar observations were reported in previous studies $([5,6,13])$, where both showed a similar degradation trend and followed a first-order reaction. Furthermore, it was difficult to remove the remaining organic matter by ozonation; further treatment was required for total removal.

$\mathrm{CN}^{-}$and $\mathrm{SCN}^{-}$were the important pollutants in coke-oven wastewater, and the concentrations varied widely. Both compounds could be oxidized by ozone to form sulfate, nitrogen and other non-toxic compounds. The $\mathrm{CN}^{-}$concentration decreased from 35 to $1 \mathrm{mg} / \mathrm{L}$, whereas $\mathrm{SCN}^{-}$decreased from 297 to $1.6 \mathrm{mg} / \mathrm{L}$ (as shown in Fig. 2d and e) in the present study. The $\mathrm{CN}^{-}$and $\mathrm{SCN}^{-}$oxidation reactions are considered to occur in three steps $[11,15]$ : (1) the oxidation of $\mathrm{SCN}^{-}$to $\mathrm{CN}^{-}$; (2) further oxidation to cyanate $\left(\mathrm{OCN}^{-}\right)$; and (3) continued ozonation of $\mathrm{OCN}^{-}$can form bicarbonate ions and nitrogen gas [16]:

$$
\begin{aligned}
& \mathrm{SCN}^{-}+3 \mathrm{O}_{3}+2 \mathrm{OH}^{-} \rightarrow \mathrm{CN}^{-}+\mathrm{SO}_{4}^{2-}+3 \mathrm{O}_{2}+\mathrm{H}_{2} \mathrm{O} \\
& \mathrm{SCN}^{-}+\mathrm{O}_{3}+\mathrm{H}_{2} \mathrm{O} \rightarrow \mathrm{CN}^{-}+\mathrm{H}_{2} \mathrm{SO}_{4} \\
& 3 \mathrm{CN}^{-}+\mathrm{O}_{3} \rightarrow 3 \mathrm{OCN}^{-} \\
& 2 \mathrm{OCN}^{-}+\mathrm{O}_{3}+\mathrm{H}_{2} \mathrm{O} \rightarrow 2 \mathrm{HCO}_{3}^{-}+\mathrm{N}_{2}
\end{aligned}
$$



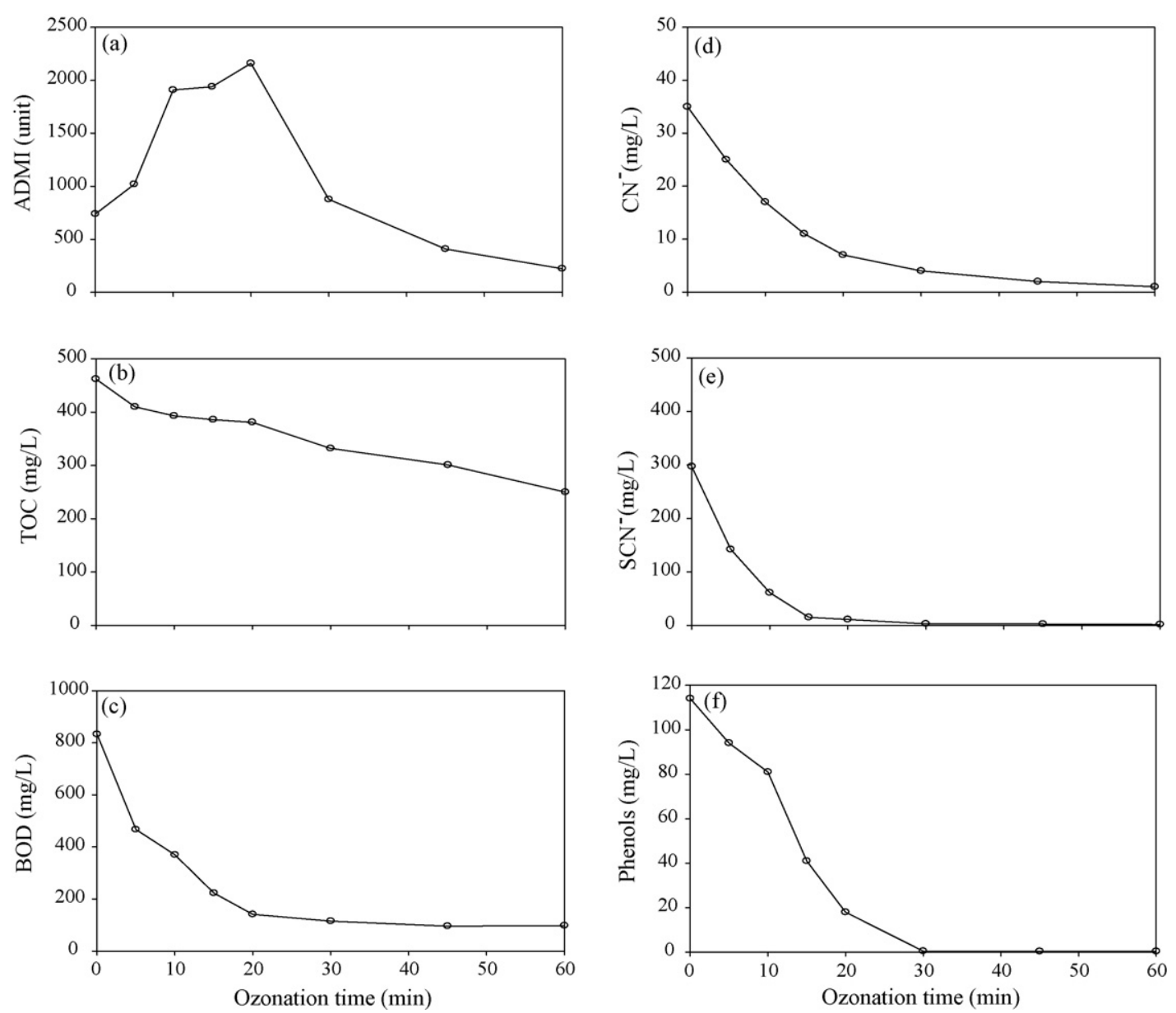

Fig. 2. The profile of (a) ADMI; (b) TOC; (c) BOD; (d) $\mathrm{CN}^{-}$; (e) $\mathrm{SCN}^{-}$; and (f) phenol of coke-oven wastewater in a bubble column reactor.

Eqs. (3a) and (3b) suggest that the regeneration of $\mathrm{CN}^{-}$ resulted from $\mathrm{SCN}^{-}$by ozone and that continued ozonation would prevent the formation of nitrite or nitrate [15]. The $\mathrm{k}_{\mathrm{R}} \mathrm{s}$ for $\mathrm{CN}^{-}$at 5, 20 and $60 \mathrm{~min}$ were $0.067,0.080$ and $0.059 \mathrm{~min}^{-1}$, and the $\mathrm{k}_{\mathrm{R}} \mathrm{s}$ for $\mathrm{SCN}^{-}$were $0.15,0.16$, and $0.087 \mathrm{~min}^{-1}$, respectively. It was noted that the $\mathrm{k}_{\mathrm{R}} \mathrm{s}$ for $\mathrm{SCN}^{-}$were larger than those of $\mathrm{CN}^{-}$. Compared with the study conducted by Van Leeuwen et al. [17], the calculated $\mathrm{k}_{\mathrm{R}} \mathrm{S}$ for $\mathrm{SCN}^{-}$were $0.028,0.019$, and $0.03 \mathrm{~min}^{-1}$ at three given times, values that are smaller than the present study; the difference was due to the applied ozone dose.

Phenols were toxic and xenobiotic to the aquatic ecosystem when discharged into the water body; these substances are on the priority control list to protect the environment and human health. The decomposition of phenols by ozone was investigated in the present study. Fig. $2 \mathrm{f}$ shows the decomposition of wastewater containing phenols, which exhibited a rapid reaction [18].

\subsection{Effect of $\mathrm{pH}$ on ozone consumption associated with pollutant removal}

\subsection{1. $\mathrm{CN}^{-}$and $\mathrm{SCN}^{-}$removal}

Eqs. (3)-(5) show that the formation and degradation of $\mathrm{CN}^{-}$ by ozone was a $\mathrm{pH}$-dependent reaction that was favorable under neutral to alkaline conditions; the results are presented in Fig. 3. The ozonation of $\mathrm{CN}^{-}$followed a pseudo-first-order reaction, since ozone and hydroxyl ions concentrations were substantially higher than $\mathrm{CN}^{-}$concentration. On the one hand, as shown in Fig. 3, the oxidation of $\mathrm{CN}^{-}$was $\mathrm{pH}-$ dependent; $\mathrm{CN}^{-}$was not well decomposed by ozone under acidic conditions. As suggested by Soto et al. [11], the sluggish oxidation of $\mathrm{CN}^{-}$was due to the hydrolysis of $\mathrm{CN}^{-}$, which formed $\mathrm{HCN}$ under acidic conditions at low $\mathrm{CN}^{-}$concentrations.

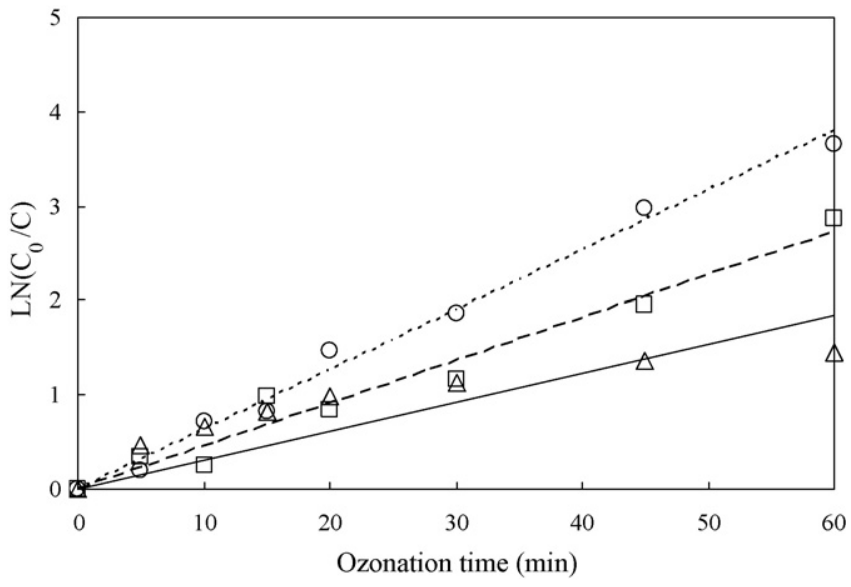

Fig. 3. Effect of $\mathrm{pH}$ on the ozonation of total cyanide. Symbol: $(\bigcirc) \mathrm{pH} 4$; ( $\square$ ) $\mathrm{pH} 7 ;(\triangle) \mathrm{pH} 9$. 


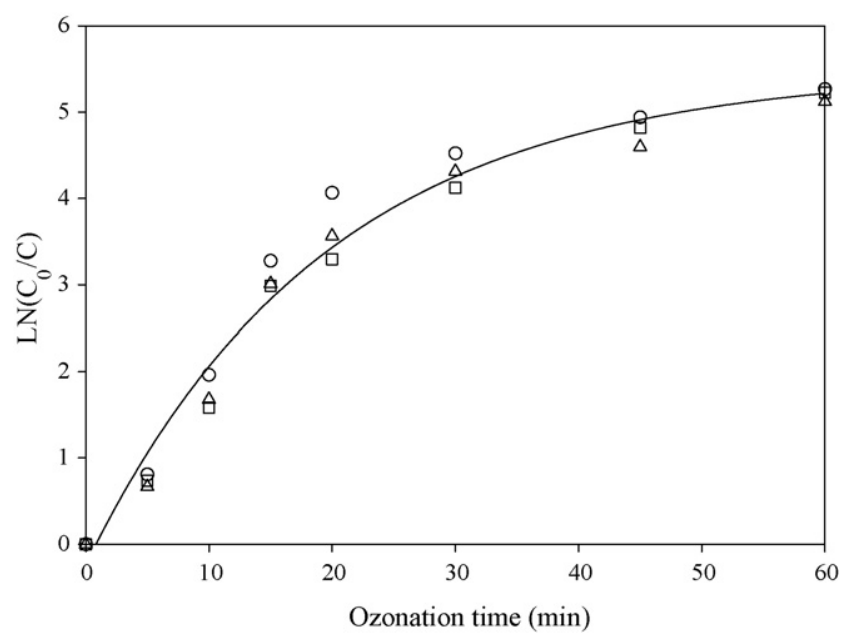

Fig. 4. Effect of $\mathrm{pH}$ on the ozonation of thiocyanate. Symbol: $(\bigcirc) \mathrm{pH} 4$; $(\square)$ $\mathrm{pH} 7 ;(\triangle) \mathrm{pH} 9$.

On the other hand, the ozonation of $\mathrm{SCN}^{-}$took place both in alkaline and acidic conditions (Fig. 4), indicating that $\mathrm{SCN}^{-}$ oxidation was $\mathrm{pH}$ independent from $\mathrm{pH} 4$ to 9 in the present study due to the very low $\mathrm{p} K_{\mathrm{a}}$ of HSCN, which was about 1.0 [11]. The ozonation of $\mathrm{SCN}^{-}$would produce $\mathrm{CN}^{-}$and sulfate, which would bring down the $\mathrm{pH}$ value; without $\mathrm{pH}$ buffering, the subsequent $\mathrm{CN}^{-}$ozonation would become slower under acidic conditions, which was consistent with experimental findings.

\subsubsection{TOC removal}

The effects of $\mathrm{pH}$ on TOC removal are illustrated in Fig. 5, revealing that the performance of TOC removal under the acidic condition was poor compared to that under alkaline and neutral conditions. TOC removal ( $\left.\eta_{\text {TOC }}\right)$ was defined as follows:

$\eta_{\mathrm{TOC}}=\left(\frac{\mathrm{TOC}_{0}-\mathrm{TOC}}{\mathrm{TOC}_{0}}\right) \times 100 \%$

As shown in Fig. 5, TOC removal was favorable under neutral to alkaline conditions, which could be observed from the varia-

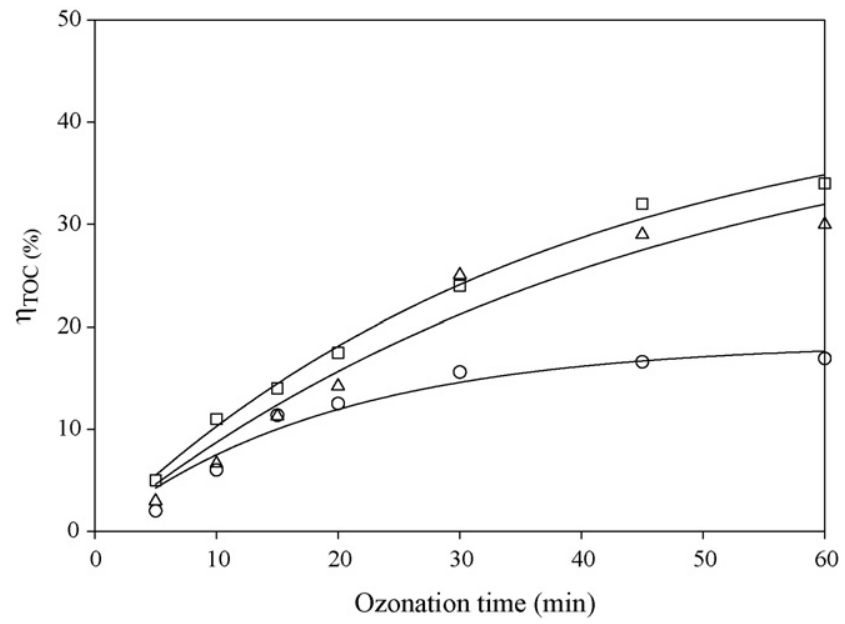

Fig. 5. Effect of pH on TOC removal ( $\left.\eta_{\mathrm{TOC}}\right)$. Symbol: $(\bigcirc) \mathrm{pH} 4$; $(\square) \mathrm{pH} 7 ;(\triangle)$ pH 9. tion trends of $\eta_{\text {TOC }}$. The highest removal ratio was about $36 \%$, indicating that the oxidation ability of ozone was not sufficient to degrade TOC entirely; under acidic conditions, the removal rate was only about $16 \%$. The $k_{\mathrm{R}}$ for TOC removal was enhanced with the increase of $\mathrm{pH} ; k_{\mathrm{R}}=0.0067,0.0096$, and $0.0085 \mathrm{~min}^{-1}$ for $\mathrm{pH} 4,7$, and 9 , respectively. Also, the $k_{\mathrm{R}}$ values for $\mathrm{pH}$ 7 and 9 were similar, suggesting that ozone decomposed and might form hydroxyl free radicals $\left(\mathrm{OH}^{\bullet}\right)$ under both conditions, which is referred to as indirect ozone reaction. The free radical reaction was less selective toward the elimination of pollutants, which would be enhanced at higher $\mathrm{pH}$. It has been reported that at a higher $\mathrm{pH}$ value with more $\mathrm{OH}^{\bullet}$, the indirect ozone reaction would prevail ([19]; Hsing et al., 2007). At $\mathrm{pH}>7$, no dissolved ozone was observed during the experiment, indicating that the indirect ozone reaction dominated and $\mathrm{OH}^{\bullet}$ was generated $[20,21]$. Thus, it could be suggested that neutral to alkaline conditions would be the favorable environment for removing organic pollutants from coke-oven wastewater. Taking into consideration the follow-up treatment and chemical consumption, the neutral condition would be the optimal choice for wastewater preozonation.

\subsubsection{Ozone consumption}

The ozonation reaction could be described by a pseudo-firstorder reaction equation with sufficient ozone input [22]; the relationship between ozone consumption ratio $\left(m_{\mathrm{O}_{3} \mathrm{R}} / m_{\mathrm{O}_{3} \mathrm{~A}}\right)$ and $\eta_{\text {TOC }}$ under three $\mathrm{pH}$ conditions was shown in Fig. 4. The $m_{\mathrm{O}_{3} \mathrm{R}}$ and $m_{\mathrm{O}_{3} \mathrm{~A}}$ were defined as follows [5,6]:

$m_{\mathrm{O}_{3} \mathrm{R}}=\int_{0}^{t} Q_{\mathrm{G}}\left(C_{\mathrm{Ai}}-C_{\mathrm{Ae}}\right) \mathrm{d} t-C_{\mathrm{Al}} V_{\mathrm{L}}-C_{\mathrm{Ae}} V_{\mathrm{H}}$

$m_{\mathrm{O}_{3} \mathrm{~A}}=Q_{\mathrm{G}} C_{\mathrm{Ai}} t$

where $C_{\mathrm{Ae}}=$ the outlet $\mathrm{O}_{3}$ concentration $\left(\mathrm{mg} / \mathrm{m}^{3}\right) ; C_{\mathrm{Al}}=$ the dissolved $\mathrm{O}_{3}$ in liquid phase; $t=$ reaction time (min).

In Fig. 6, the linear regression could be calculated and expressed with the determined coefficient $\left(R^{2}\right)=0.99$, revealing a clear relationship between $m_{\mathrm{O}_{3} \mathrm{R}} / m_{\mathrm{O}_{3} \mathrm{~A}}$ and $\eta_{\mathrm{TOC}}$ that was

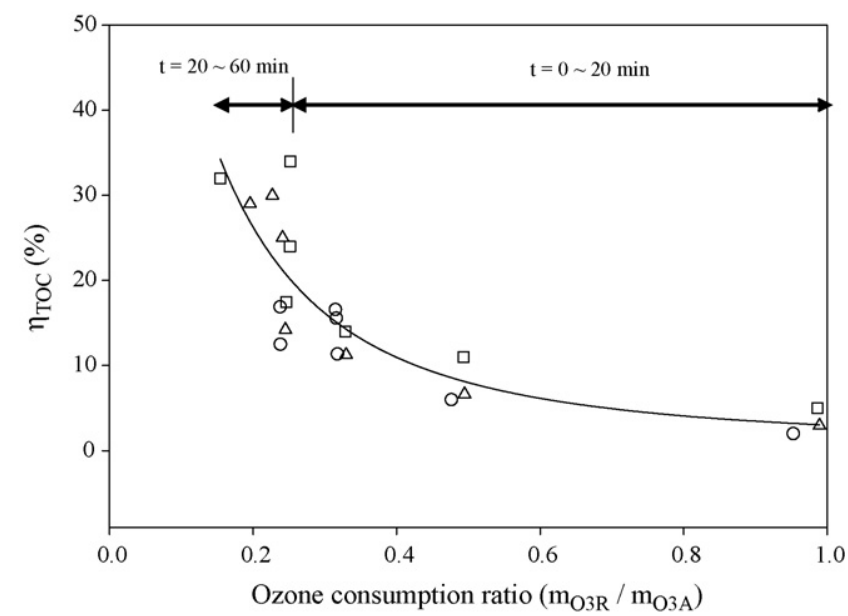

Fig. 6. The correlation of TOC removal $\left(\eta_{\mathrm{TOC}}\right)$ and ozone consumption ratio $\left(m_{\mathrm{O}_{3} \mathrm{R}} / m_{\mathrm{O}_{3} \mathrm{~A}}\right)$ under different $\mathrm{pH}$ conditions. Symbol: $(\bigcirc) \mathrm{pH} 4 ;(\square) \mathrm{pH} 7 ;(\triangle)$ pH 9. 
independent of $\mathrm{pH}$ variation. It could be observed that the ozone consumption approached 1 at the early stage (within the period $t<20 \mathrm{~min}$ ) of ozonation, suggesting that most of the ozone was used to degrade pollutants; the $\eta_{\text {TOC }}$ was less than $10 \%$, indicating that only part of the ozone was used to degrade organic pollutants. After the initial stage, the consumption ratio reverted to about 0.2 , but $\eta_{\text {TOC }}$ increased from $10 \%$ to $30 \%$, suggesting that easily degraded pollutants (such as $\mathrm{CN}^{-}$and $\mathrm{SCN}^{-}$) were degraded almost entirely. From previous reports, the reaction rate constants for $\mathrm{CN}^{-}$and $\mathrm{SCN}^{-}$were about 0.37 and $0.034 \mathrm{~min}^{-1}$ [17], which were about 3.5 times the TOC reaction rate constant presented in this study. Nonetheless, about $80 \%$ of the unreacted ozone gas escaped into the vent in the later ozonation stage (20-60 $\mathrm{min}$ ), which was shown through monitoring of the off-gas, indicating that the TOC oxidation approached steady state.

\subsection{Effect of ozonation on biodegradability and inhibition}

\subsubsection{Biodegradability}

The effect of ozonation on biodegradation was investigated by conducting additional experiments to study the $\mathrm{BOD}_{5} / \mathrm{COD}$ ratios (Fig. 7), which served as one criterion for evaluating the biodegradability of the wastewater. As shown in Fig. 7, the initial $\mathrm{BOD}_{5} / \mathrm{COD}$ values for three experimental conditions were all around 0.52 initially, reflecting relatively good biodegradability. As the ozonation time passed $20 \mathrm{~min}$, the $\mathrm{BOD}_{5} / \mathrm{COD}$ value decreased quickly from 0.52 to about 0.1 and stabilized, indicating that most biodegradable materials and/or easily degraded substances were oxidized, while difficult-to-degrade ozonated byproducts were formed, thus driving $\mathrm{BOD}_{5}$ concentration to $95 \mathrm{mg} / \mathrm{L}$ while $\mathrm{COD}=890 \mathrm{mg} / \mathrm{L}$ at ozonation time $=60 \mathrm{~min}$. The results revealed that extended ozonation would not enhance biodegradation or the performance of the subsequent treatment.

To investigate the effect of ozonated byproducts on the performance of the subsequent treatment unit, i.e., the activated sludge process, specific oxygen uptake rate (SOUR) tests were performed in this study; SOUR was a rapid measure of influent

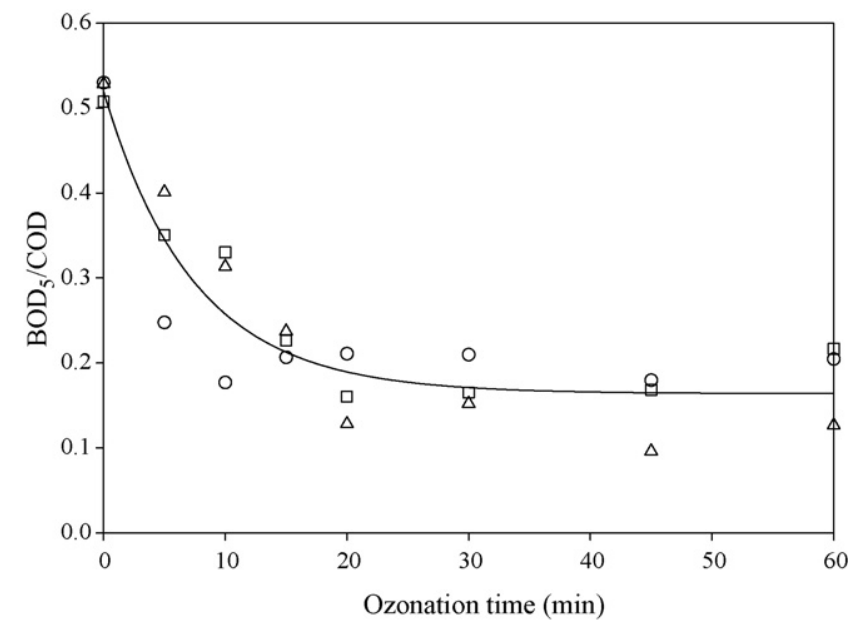

Fig. 7. Changes in biodegradation during ozonation at various conditions. Symbol: $(\bigcirc) \mathrm{pH} 4 ;(\square) \mathrm{pH} 7 ;(\triangle) \mathrm{pH} 9$.

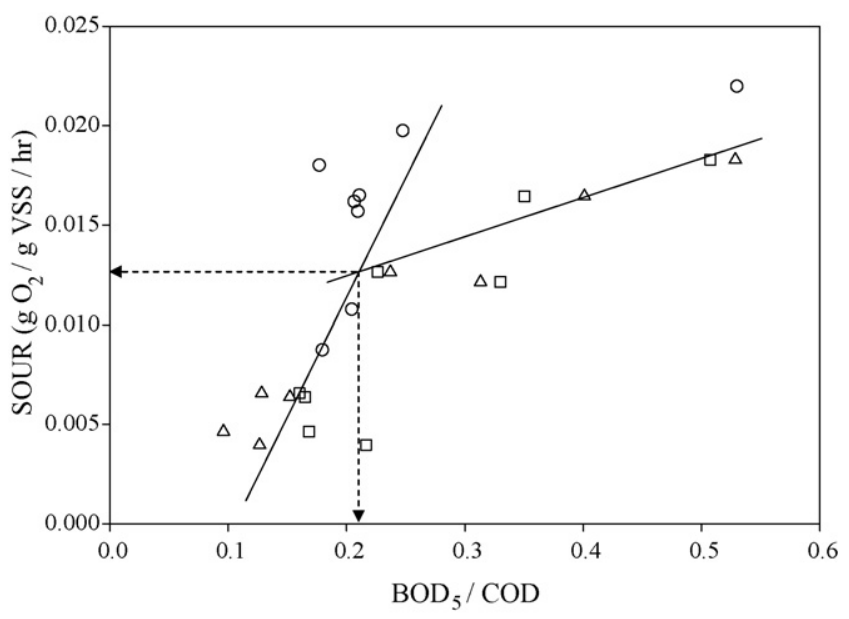

Fig. 8. Correlation of SOUR and $\mathrm{BOD}_{5} / \mathrm{COD}$ during ozonation at various conditions. Symbol: $(\bigcirc) \mathrm{pH} 4 ;(\square) \mathrm{pH} 7 ;(\triangle) \mathrm{pH} 9$.

organic load and biodegradability, the results of which could indicate the presence of toxic or inhibitory material in samples as well as the degree of stability. SOUR (unit: $\mathrm{g} \mathrm{O}_{2} / \mathrm{g}$ solid/h) was defined as:

SOUR $=\frac{\left(\mathrm{DO}_{i}-\mathrm{DO}_{i+1}\right)}{\mathrm{VSS} / t}$

where $\mathrm{DO}=$ dissolved oxygen $(\mathrm{g})$; VSS $=$ volatile suspended solid (g).

Fig. 8 presents the relationship between SOUR and $\mathrm{BOD}_{5} / \mathrm{COD}$; it is clear that a decrease in SOUR coincided with a decreasing $\mathrm{BOD}_{5} / \mathrm{COD}$ value, suggesting that $\mathrm{SOUR}$ was higher when more biodegradable substances were present. From Fig. 8, it was observed that the ratio of SOUR and $\mathrm{BOD}_{5} / \mathrm{COD}$ under the acidic condition was larger than the ratio under neutral and alkaline conditions; an optimum operational parameter could be set as SOUR $=0.0133 \mathrm{~g} \mathrm{O}_{2} / \mathrm{g} \mathrm{VSS} / \mathrm{h}$ and $\mathrm{BOD}_{5} / \mathrm{COD}=0.21$, $t=20$ min coincidently. Microbial respiration was dominant for the samples within the early stage of ozonation due to high SOUR values when more biodegradable substances are present.

As seen in Fig. 8, the SOUR values ranged between 0.012 and $0.02 \mathrm{O}_{2} / \mathrm{g} \mathrm{VSS} / \mathrm{h}$, indicating that good BOD removal, as well as good sludge settling, could be achieved [23]. On the other hand, as suggested in the previous report, SOUR value $<0.012$ $\mathrm{O}_{2} / \mathrm{g} \mathrm{VSS} / \mathrm{h}$ indicated toxicity, consistent with the observation presented in this study about ozonated byproduct formation.

\subsubsection{Inhibition}

Toxicity was an important factor for considering the effect of ozonation on coke-oven wastewater, especially followed by the activated sludge process. The results of the inhibition of aerobic microorganisms by ozonation are presented in Fig. 9. The inhibition (I) could be defined as follows [24]:

Inhibition $=\left(\frac{1-\text { SOUR }_{\text {corrected }}}{\text { SOUR }_{\text {baseline }}}\right) \times 100 \%$

where SOUR $_{\text {corrected }}=$ SOUR $_{\text {measured }}-$ SOUR $_{\text {background }}$.

The inhibition decreased as the ozonation increased, suggesting that toxic substances were destroyed by ozone and converted 


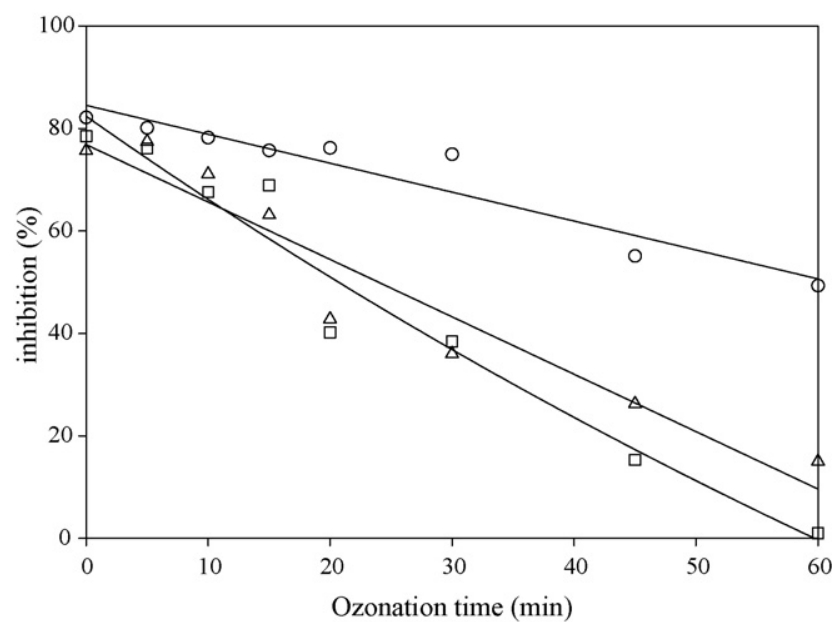

Fig. 9. Changes in inhibition during ozonation at various conditions. Symbol: (○) $\mathrm{pH} 4$; $(\square) \mathrm{pH} 7 ;(\triangle) \mathrm{pH} 9$.

to less toxic or non-toxic substances. The decreasing trend of $I$ values for $\mathrm{pH} 4$ was slower than that of $\mathrm{pH} 7$ and 9, indicating that inhibition of coke-oven wastewater performed after ozonation under neutral and alkaline conditions would be better than that performed under acidic conditions. As shown in Fig. 9, the inhibition of aerobic microorganisms under neutral and alkaline conditions was lower than $20 \%$, even approaching $0 \%$; it was clear that lower inhibition would benefit the subsequent biological treatment. Although poor inhibition mitigation under acidic conditions was observed, the inhibition decreased from $83 \%$ to $52 \%$, and a certain amount of toxic substance was removed from the system. The results demonstrated that ozonation could effectively reduce the effect of inhibition on aerobic microorganisms, suggesting that it is a promising method to decontaminate and detoxify coke-oven wastewater. This study suggests that effective and feasible treatment approaches should achieve a balance between detoxification and enhancement of biodegradability. Thus, the characteristic ozonation time for the present study was suggested as $20 \mathrm{~min}$ based on the rationale mentioned above. Within ozonation time $=20 \mathrm{~min}$, both ozone consumption and pollutant removal were efficient, enabling detoxification and biodegradability to be maintained without negatively affecting the subsequent biological treatment process.

\section{Conclusions}

The chemical and biological characteristics of raw coke-oven wastewater treated by ozone were investigated and discussed in this study. Selected water quality parameters, such as ADMI, BOD, TOC, $\mathrm{CN}^{-}$and $\mathrm{SCN}^{-}$, were tested, and the following conclusions were drawn:

- The removal of ADMI, TOC, $\mathrm{BOD}, \mathrm{SCN}^{-}$, and $\mathrm{CN}^{-}$reached $70,45,88,99$, and $97 \%$ after $60 \mathrm{~min}$ of ozonation under neutral conditions, respectively. Not all pollutants could be removed entirely by extended ozonation; treatment processes had to be added or recombined to meet effluent standards.
- The $\mathrm{CN}^{-}$and TOC removal were $\mathrm{pH}-$ dependent; both performed well under alkaline conditions, but the removal of $\mathrm{SCN}^{-}$was $\mathrm{pH}$ independent. The $\eta_{\mathrm{TOC}}$ reached about $36 \%$ under $\mathrm{pH} 7$ and 9 conditions, an amount double that under acidic condition due to indirect ozonation.

- Both the ozone consumption ratio and $\eta_{\text {TOC }}$ were independent of the $\mathrm{pH}$ variation; only part of the ozone was utilized to oxidize the pollutant within the period of ozonation time $<20 \mathrm{~min}$. Afterward, the consumption ratio decreased to 0.2 and $\eta_{\text {TOC }}$ increased to $30 \%$, indicating that easily degraded pollutants (such as $\mathrm{CN}^{-}$and $\mathrm{SCN}^{-}$) were degraded almost entirely.

- Biodegradation was not enhanced by observing the $\mathrm{BOD}_{5} / \mathrm{COD}$ ratio, which decreased from 0.52 to about 0.1 , indicating that the pretreatment was not beneficial to the subsequent activated sludge process in terms of biodegradability, especially for extended ozonation.

- The inhibition effect of ozonated coke-oven wastewater on aerobic microorganisms was more significant under acidic conditions than under neutral and alkaline conditions, suggesting that the preozonation could reduce the toxicity impact and benefit the subsequent biological treatment unit.

- The optimal pretreatment operation was pH 7 and ozone contact time $<20 \mathrm{~min}$ to achieve decolorization, toxicity reduction, and organic pollutant removal.

\section{Acknowledgements}

The authors would like to thank the China Steel Corporation for financially supporting this research under Contract no. 94Y92-0006.

\section{References}

[1] S.-S. Kim, K.-M. Lee, Determination and characteristic interpretation of color-causing materials in coke plant wastewater, J. Ind. Eng. Chem. 10 (2004) 52-59.

[2] World Bank, Industrial Pollution Prevention and Abatement: Coke Manufacturing, Draft Technical Background Document, Washington, DC, 1995.

[3] M.K. Ghose, Physico-chemical treatment as a suitable option for treatment of coke plant effluent, IE (I) J.-CH 84 (2004) 50-54.

[4] W. Nishijima, G.E. Speitel Jr., Fate of biodegradable dissolved organic carbon produced by ozonation on biological activated carbon, Chemosphere 56 (2004) 113-119.

[5] H.J. Hsing, P.C. Chiang, E.E. Chang, Effects of selected parameters on decolorization and decomposition of Acid Orange 6, Environ. Eng. Sci. 23 (2006) 833-843.

[6] H.J. Hsing, P.C. Chiang, E.E. Chang, Y.S. Li, Decolorization and mineralization of Tropaeolin $\mathrm{O}$ in water by ozonation with UV radiation, Ozone Sci. Eng. 28 (2006) 9-16.

[7] I. Arslan, I.A. Balcioglu, Advanced oxidation of raw and biotreated textile industry wastewater with $\mathrm{O}_{3}, \mathrm{H}_{2} \mathrm{O}_{2} / \mathrm{UV}-\mathrm{C}$ and their sequential application, J. Chem. Technol. Biotechnol. 76 (2001) 53-60.

[8] M.F. Sevimli, H.Z. Sarikaya, Ozone treatment of textile effluents and dyes: effect of applied ozone dose, $\mathrm{pH}$ and dye concentration, J. Chem. Technol. Biotechnol. 77 (2002) 842-850.

[9] C. Wang, A. Yediler, D. Lienert, Z. Wang, A. Kettrup, Ozonation of an Azo Dye C.I. Remazol Black 5 and toxicological assessment of its oxidation products, Chemosphere 52 (2003) 1225-1232.

[10] P. Ning, H.-J. Bart, Y. Jiang, A. de Haan, C. Tien, Treatment of organic pollutants in coke plant wastewater by the method of ultrasonic irradiation, 
catalytic oxidation, and activated sludge, Sep. Purif Technol. 41 (2005) 133-139.

[11] H. Soto, F. Nava, J. Leal, J. Jara, Regeneration of cyanide by ozone oxidation of thiocyanate in cyanidation tailings, Miner. Eng. 8 (1995) 273-281.

[12] P. Karageorgos, A. Coz, M. Charalabaki, N. Kalogerakis, N.P. Xekoulotakis, D. Mantzavinos, Ozonation of weathered olive mill wastewaters, J. Chem. Technol. Biotechnol. 81 (2006) 1570-1576.

[13] Y.-C. Hsu, H.-C. Yang, J.-H. Chen, The enhancement of the biodegradability of phenolic solution using preozonation based on high ozone utilization, Chemosphere 56 (2004) 149-158.

[14] N.-C. Shang, Y.-H. Yu, The biotoxicity and color formation results from ozonation of wastewater containing phenol and aniline, J. Environ. Sci. Health A36 (2001) 383-393.

[15] J. Monteagudo, L. Rodríguez, J. Villaseňor, Advanced oxidation processes for destruction of cyanide from thermoelectric power station waste waters, J. Chem. Technol. Biotechnol. 79 (2004) 117-125.

[16] J.A. Zeevalkink, D.C. Visser, P. Arnoldy, C. Boelhouwer, Mechanism and kinetics of cyanide ozonation in water, Water Res. 14 (1980) 13751385 .
[17] J. Van Leeuwen, B. Badriyha, S. Vaczi, Investigation into ozonation of coal coking processing wastewater for cyanide, thiocyanate and organic removal, Ozone Sci. Eng. 25 (2003) 273-283.

[18] P.C. Singer, M.D. Gurol, Dynamics of the ozonation of phenol-II mathematical simulation, Water Res. 17 (1983) 1173-1181.

[19] Y. Zeng, P.K.A. Hong, D.A. Wavrek, Chemical-biological treatment of pyrene, Water Res. 34 (2003) 1157-1172.

[20] L. Li, W. Zhu, P. Zhang, Z. Chen, W. Han, Photocatalytic oxidation and ozonation of catechol over carbon-black-modified nano- $\mathrm{TiO}_{2}$ thin films supported on Al sheet, Wat. Res. 37 (2003) 3646-3651.

[21] C. Tang, V. Chen, The photocatalytic degradation of reactive black 5 using $\mathrm{TiO}_{2} / \mathrm{UV}$ in an annular photoreactor, Wat. Res. 38 (2004) 2775-2781.

[22] R.G. Rice, Application of ozone for industrial wastewater treatment-a review, Ozone: Sci. Eng. 18 (1997) 477-515.

[23] APHA, Standard Methods for the examination of Water and Wastewater, 19th ed., American Public Health Association, Washington, DC, 1995.

[24] B.-N. Lee, Study on catalytic wet air oxidation of ferrocyanide or 2,4-dichlorophenol solutions. Ph.D. dissertation, National Sun Yat-Sen University, Kaohsiung, Taiwan; 2001. 